\title{
Hvordan kan sykepleiere kartlegge barns smerte?
}

Gode kartleggingsverktøy kan hjelpe sykepleiere å finne ut hvor store smerter et barn har.

Barn Smerte Kartlegging

Sykepleien 2020108 (80444) (e-80444)

DOI: 10.4220/Sykepleiens.2020.80444

\section{Hovedbudskap}

Å kartlegge barnets smerter er en vesentlig del av den smertelindrende behandlingen. Manglende systematisk kartlegging kan føre til underbehandling. For å kartlegge grad av smerte behøver sykepleiere gode kartleggingsverktøy. På verdensbasis finnes en rekke verkt $\varnothing \mathrm{y}$ for å evaluere smerte, men det finnes ikke ett verkt $\varnothing \mathrm{y}$ som kan benyttes til barn i alle aldre. I denne artikkelen presenteres fire av fem verktøy som er inkludert i den nasjonale fagprosedyren for smertekartlegging av barn. 